DiederikJ. W. Meijer*

\title{
Marginal and Steppic Areas as Sources for Archaeological Debate: A Case for "Active Symbiosis" of Town and Country
}

\section{Introduction}

The division of landscapes suggested by the organisers of this conference is a striking one. Whereas the first, constituent space comprises the base, that is, the actual physical surroundings, the other two are divisions of an entirely socio-political and socio-economic nature, and the word "space" there is entirely conceptual. Into these conceptual spaces, the organisers have placed "raw topics", providing concrete handles for the nitty-gritty, i.e. actual subjects for papers. Since the scene is set in Northern Mesopotamia and Northern Syria, the actual space we are dealing with (the constituent space) partly has a steppe character, and partly concerns a marginal area in terms of agriculture: it hovers around the $200 \mathrm{~mm}$ isohyet. The present paper devotes itself to what is called confederate space, mainly discussing aspects of raw topics 3 and 8, i.e. "nomadism" and political structures.

Archaeological analogies with present or sub-recent ethnographic datasets are famously full of pitfalls, and this goes a fortiori for studies about nomadic ways of life. Apart from such analogies, however, virtually our only source for the nomadic way of life in the ancient Near Eastern Middle Bronze Age - which is the period I am concerned with here - is the textual evidence from Mari. Unfortunately, rich as that material may be, for the purpose at hand it is not ideal. It is no secret that these texts were written with the bias of a settled urban population, who were mainly concerned with procuring the results of the cultivation of wheat and barley, and who concentrated on the sustained effort to safeguard their resources, the fields, the water and the concomitant infrastructure. The texts may therefore at least be suspected of not reflecting the situation outside the towns in a balanced way. The bias opposed the settled, urban society of kings, civil servants, soldiers, craftsmen and traders, to the other sector, the roaming tribes said to be basically inimical to the settled urban centres, the unruly "nomads" with their sheep and goats, who often had to be forced "to see reason" by the troops of the urbanites. Additionally, also our modern way of evaluating the texts is sometimes biased. Even after what Larsen wrote about perceptions induced by ancient texts, ${ }^{\text {I }}$ the latter are often still treated as if they yield direct, "positive" (= positivistic) knowledge.

\footnotetext{
* Universiteit Leiden. This contribution contains phrases from a paper read at the Paris ICAANE of 2002; since the latter's publication seems to have been indefinitely postponed, I feel free to use some of my earlier text here. Since 2002 two major pertaining publications have appeared: Nicolle 2004 and Szuchman 2009 , both containing papers which argue parallel themes; yet I think that my (adapted) ideas from 2002 still deserve wider publicity. I Larsen I988, I74f.
} 
I am not suggesting that anyone has recently denied the importance of the socio-economic role of those population elements that are described as less settled. Nonetheless a certain scientific bias still persists toward those roamers. ${ }^{2}$ Often they are treated rather indifferently or cavalierly, probably because they are difficult to grasp compared to what the texts and archaeology can tell us about settled people.

\section{Terminology}

In order to clarify the terms used, I think we may safely exclude nomadism as such from our overview. This is because this term has been used both as too general and as too specific. Taking up the latter, specific meaning, I would like to define nomadism here as a way of life entirely dependent on non-sedentary exploitation of available natural resources. ${ }^{3}$ Khazanov 4 discussed the difficulty of distinguishing between nomads and pastoralists. Wirth ${ }^{5}$ had discussed this point earlier, and he was followed closely in an overview by Van Driel, who decided to use nomads anyway, conceiving of them as sprinkled with "an ample dose of ethnicity". ${ }^{6}$ However, I prefer to distinguish between pastoralists and nomads, and will from now on speak of pastoralists in the context of the Middle Bronze Age in Northern Mesopotamia and Syria. Excluding Nomadism, for the region and period concerned, rests on my conviction that there simply was too little space for anyone to roam about forever, even for small groups: the available land had been, or was in the process of being "colonised" by urban-induced rule, leaving little room for an existence entirely based on hunting, gathering, or other pastimes devoted to structurally unsettled subsistence.7

Pastoralism denotes a way of living which mainly involves the herding of animals; sometimes it is sub-understood that the herders travel over long distances and periods, but this is certainly not a necessary condition, either conceptually or in reality. The herding is done, everywhere in the world, in areas where either there is no fixed plant cultivation going on, or where such cultivation leaves fodder on the fields after the harvest. Especially in the latter case there must be a necessary understanding between the owners of the land in question and the pastoralists. The important thing is, that the practice of herding (and of animal husbandry in general) is tied in with the socio-economic life of the settled cultivators.

The term transhumance has been coined a long time ago for a specific kind of pastoralism, i.e. one where certain itineraries are repeatedly followed by a circumscribed group

2 See now also Bernbeck 2008, 44f.

3 The OED defines nomadism as: "The practice, fact or state of living a wandering life". Pastoralist: "(...) of or pertaining to shepherds or their occupation". Transhumance: "seasonal moving of livestock to regions of different climate".

4 Khazanov 1984, 19-24.

5 Wirth I97I, 254-27I.

6 Van Driel 200I, 88. On ethnicity, see below. See now also Khazanov 2009.

7 Meijer 2000. 
of people in a set seasonal pattern. Until recently the Yörük in southern Turkey ${ }^{8}$ provided a good example, to limit ourselves to the general neighbourhood.

This is quite different from something still witnessed today: the seasonal movement with herds of sheep and goats over relatively long distances (e.g., from Palmyra to the north Syrian Jazirah) by specialized herders, who are paid for this service by entirely sedentarized, urban-based herd-owners. One could call this phenomenon contract herding. It is probable that this occurred also in the Syrian Middle Bronze Age, and we know it from other sources as well, e.g. from the Ur III texts. Theoretically, such contract herding might be practiced by whole families or "tribes", but they would be confined to certain specific itineraries and seasonal periods, in both cases by order of the owners. To my mind the important difference both in terminology and in kind is predicated on ownership of the herds: contrasted with this contract herding, we speak of pastoralists when the herders are the owners of the animals they herd as a way of sustenance.

If then, for the sake of clarity and simplicity, we agree on calling those who practice animal husbandry in Northern Syria and Mesopotamia pastoralists, are we to view them as an ethnic group or as a more general kind of ad hoc grouping of people in a reaction to fluctuating resources? And to what extent can archaeology contribute anything useful to these questions?

\section{Ethnicity and tribes}

The 44th Rencontre Assyriologique Internationale in Leiden was devoted to the theme of ancient oriental ethnicity, of course treated mainly from the point of view of the ancient cuneiform texts. 9 Texts indeed would seem to be the primary source for a classification of the ancient social structures and processes, but as was perhaps to be expected, during this Rencontre the highly interesting discussions did not proceed very far beyond disagreement on the content of the term ethnicity and the exposition of differences in, e.g., "tribal" names. Are we trying to denote shared language, symbolism and creed, history, sustenance strategies or territoriality, or specific combinations of these facets?

Modern usage of the term ethnicity has evolved from purely anthropological definitions to a widely used, politically laden concept reflecting the socio-political tensions that exist in many countries of the modern world. ${ }^{10}$ Furthermore, also in our modern world, the content and perception of ethnic descriptions can change radically through time. For in-

\footnotetext{
8 Bates i973.

9 The Rencontre in Leiden was held in $\mathbf{2 0 0 2}$, and published in van Soldt et al. 2005 .

Io Our modern concept of ethnicity, laden with these tensions and connotations of discrimination, probably developed as a result of the strong feelings of nationalism that have been fostered and manipulated since the middle of the nineteenth century AD, but especially since the breakdown of traditional colonialism and the resulting emergence of new states after the Second World War.
} 
stance, where once, just after the Second World War, the qualification "Italian" or "Japanese" stood for shoddy products, within 30 years (!) the connotation had changed to stylish and well-made, advanced products; the way the people behind these products were perceived changed in the same vein. Since our gauge of chronology in the ancient Near East is infinitely coarser, we should be careful in viewing all mentions of such entities as "the Amorites" in one and the same light. It would therefore seem best to restrict our use of the term and concept ethnicity to those occasions where we can show that ancient rulers or parties manipulated the "otherness" of others in order to achieve their political or socio-economic goals. At least this modern understanding of the term gives us a definite framework, an agreement on the basis of which to disagree; it is after all our perception of the past that we are trying to formulate, in order to investigate subsequently whether and how it can be tested.

It turns out that it is difficult to find cases where such an "otherness" was indeed used to thwart the ideals of specific groups in the ancient Near East, or to further one's own aims at someone else's cost. The Amorites are the best known ethnic grouping we can isolate in the Ancient Near East for our period of concern. Thus, taking Shibutani - Kwan's definition as our point of departure, ${ }^{\text {II }}$ the question of ethnicity in our context of the Middle Bronze Age Syria and Mesopotamia is essentially reduced to the question whether these Amorites can be said to have practiced pastoralism as their main method of economic sustenance, and were discriminated because of it.

The Amorites and their sub-divisions were seen by others as recognizable entities, they probably saw themselves as such, and their genealogy was at times emphasized. Furthermore the ancients distinguished between the Amorite language and their various own ones, and in modern linguistics we speak of an Amorite onomasticon. But how pervasive was this distinction in practice, especially as denoting a different way of life in a specific region? This is difficult to gauge. The distinction sometimes made between Amorites and Akkadians in some contexts is striking,, ${ }^{22}$ but again, no strong discrimination in the modern sense can be noted. Such often repeated notions that "they did not bury their dead, they lived in tents" etc. are obvious contradistinctions to the urban, settled way of life, undoubtedly used to bolster the cohesive spirit of the urban, settled population, perhaps even to indoctrinate one's city-based subjects against these unruly dangers from the steppe. But how closely correlated were the notions of "Amorite" (or their sub-divisions, like the Tidanum) and "unruly danger from the steppe" really for the man in the street, at a time when

II Shibutani - Kwan I965, 47: “ ... a number of people who see themselves as similar with regards to shared heritage, whether genuine or supposed, and who are regarded by others as such". "Heritage" here is quite imprecise. See, e.g., Emberling - Yoffee I999, but also Buccellati's remarks about our difficulties of gauging the content of "tribal names", like that of the Yaminites (Buccellati I990, I05f.).

I2 See for instance Charpin 200I, 28, where Hammurabi of Babylon on his seal calls himself "king of Amurrum (...) son of Sin-muballit whose heir (he is), king of Akkad", suggesting that as king of Amurru he is also king, like his father, of Akkad. 
the Amorites were accepted in the higher echelons of society?³ Although the Amorites were in principle identifiable as a group, many of them lived in towns, and it seems they were not consistently segregated nor noticeably discriminated against in any special way.

A different side of this same ethnic coin is that nothing prevents us from assuming that also a sizeable number of Hurrian-speaking people were professionally engaged in animal husbandry in the region - we simply do not know, especially concerning the very beginning of the second millennium. These Hurrians were certainly there, however. ${ }^{14}$ In this context it is worth pointing out, against Zohar and Buccellati, ${ }^{15}$ that correlating a specific way of life with a language group is a self-defeating proposition; this is true $a$ fortiori of cases where the only language trace left us to judge from consists in deficiently written texts. Thus the pastoralist way of life cannot be said to be ethnically ascribable with any degree of certainty, nor is there any solid evidence that this way of life led to systematic discrimination. In the same vein, when we speak of tribes the association of the word is often that of the sub-recent Bedouin. There, specific forms of familial cohesion and decision structures obtained, as well as specific combinations of nomadism and sedentism..${ }^{16} \mathrm{~A}$ high degree of mobility is ascribed to them, predicated on fast animals such as the camel and the horse. Neither animal was in use during the period we are discussing. In short, the concept of tribe is another one that is difficult, and using it may cloud issues.

I3 See Buccellati I966, esp. 325f. and 337f. and, on the question of propagandistic mention, 336. Silluš-Dagan for example was an Amorite governor of Simurrum during the Ur III period. During the subsequent Isin-Larsa and Old Babylonian periods Amorites were to be found in all levels of Mesopotamian and Syrian society, as is well known. I suggest below that the mention of the limes (muriq Tidnim) against the Tidanum built by Šulgi and Šusin may be seen as propaganda measures taken in times of economic imbalance, as are, e.g., the derogatory remarks about the Guti found in the Curse of Agade (cf. Schwartz I995, 250). In these instances one could perhaps make a case for conscious discrimination, but the question remains whether (and how) the measures were perceived by the general population, and whether they reached, beyond mere propaganda, into the field of socio-economic consequences.

I4 The presence of Hurrians (i.e., Hurrian speaking people) is well attested for the later third millennium, and since a "Hurrian nation" exists in the second half of the second millennium there can be no doubt that also in the first half of the second millennium there were Hurrians in Northern Syria and Northern Mesopotamia, and they were not confined to cities (cf. next note). Cf. also Lion I996 (I am very grateful to Prof. D. Charpin for this reference). For the Middle Assyrian period, see e.g. Freydank I980.

I5 Zohar I992, esp. I75; Buccellati I990, IIO. There, on page Io9 Buccellati hypothesizes that ancient usage of the term Hurrian might be reserved for urban populations, but as he indicates, there is no evidence for such a distinction.

I6 E.g., Musil I928, von Oppenheim I939, Thesiger 1959. An overview of the Amorites by M. Streck provides some thoughts about the tribal structure of this ethnic group (Streck 2002). 


\section{“Dimorphism"}

Among the many merits of the important article by Buccellatir7 on what he calls the nomadisation of the middle Euphrates, his emphasis on the differences between the south, middle and the north of Syria in terms of the causes of pastoralism (as represented in his fig. 6) is important. Yet his implicit association ${ }^{\mathrm{I} 8}$ of "autonomous pastoralism" with Amorites is, I think, subject to qualification on two counts: first, referring to the discussion above, we should be less ready to take such ethnic associations for granted; second, the term autonomous pastoralism suggests, to my mind, a form of existence that is too one-sided to be practicable, even for the relatively well-known region around Mari. ${ }^{19}$

Elsewhere I have discussed my hypothesis that it is not by accident that many important sites (towns and cities) in Northern Syria and Northern Mesopotamia are situated in the marginal zone where rain-fed agriculture on the one hand does not quite provide a dependable basis throughout the years, and where on the other hand irrigation on a large scale is impracticable. ${ }^{20}$ It is here that people easily revert to emphasis on the complementary husbanding of herds, when natural causes such as bad harvests or social factors such as taxes or other kinds of coercion force them to. For them, it means a shifting emphasis rather than a structural change of lifestyle, since some of them were always engaged in herding anyway. We are dealing with an area where the lie of the land favours animal husbandry. There were sufficient water holes and wadis, there was vegetation along these and along the main rivers, and sufficient pasture still left between the regions of cereal cultivation (pasture to be used in covenant with the owners of the land). It is also the area where closest contact is possible between those involved in both production modes and the markets of the towns, that is, where the connecting traffic faces the shortest routes.

Although the land for pasture was at this time always claimed to belong to one of the centres (or rather to private owners living in these centres - we do not have sufficient information on landownership in this region), these centres needed the pastoral element as much as the latter needed the former. Returning to those population elements that are usually described as moving about and nomadic and distinct from the settled population, I think that Rowton's “dimorphism” should be adapted and used in a different vein than he imagined. ${ }^{21}$ For the region and period under consideration we should take up and adapt an old idea, discussed for instance by Adams, ${ }^{22}$ and view the complementary ways of life called agriculture and pastoralism as two sides of the same coin, that is, handled by the same

I7 Buccellati I990.

I8 Buccellati I990, I09.

I9 See Charpin I99I, IIf., where, however, a rather strict division between “agriculteurs sédentaires" and "pasteurs nomades" is maintained.

20 Meijer I999.

2 I Summarized, e.g., in Rowton I980, with literature.

22 Adams I974. 
"families". Something similar is described by Hole for the Zagros region in modern times, as well as for the Syrian steppe around Lake Assad by Kaplanian and by Lewis. ${ }^{23}$ The towns and cities served as market places, where products from both sides, and news, were exchanged.

But what has not been emphasized so far, I think, is that these markets should not be seen as places of exchange between the settled and the unsettled, but, more comprehensively, as markets for all kinds of products produced by several producers from the same mixed backgrounds. Families or lineages $\mathrm{A}$ and $\mathrm{B}$ and $\mathrm{C}$ all exchanged goods from mixed backgrounds, pastoral and agricultural, undoubtedly specializing, but specializing in quality rather than in kind of produce. There is ample room for such a hypothesis since it is, for instance, not often specified from where products for the Mari palace arrive there, or what part of the economy they represent: are they self-produced on palace land, are they a form of tax (tithes), tribute, extraction, or purchase? Of course cereals and wool as well as other products are mentioned, but we would like to know much more about their places of origin, and how they were procured for the palace. The king and other members of the elite owned fields in the countryside from which they derived their products, and it is surmised that the people working those fields were employed by the field owners, but this still leaves gigantic parts of the local economy unaccounted for: were they employed as serfs, or as paid day-workers, as tenants, and how did the man in the street in the towns procure his sustenance? Such aspects remain unclear for the moment, despite such important studies as Reculeau 2008 and 2009 on the relations between town and countryside around Mari.

It is also important to realize that "the town" generally mentioned in these contexts is a posited extension of "the palace", since in the present case no detailed information other than that of the palace is available: the evidence discussed so far derives from the cuneiform texts from the palace. Town and country, or urban and rural, are oppositions which easily predispose us toward certain social connotations, such as educated vs. wild, ruler vs. ruled or consumer vs. producer. Although in the minds of the townspeople there existed something like the opposition between namlakatum and naw $u m$, this does not mean that the two could not overlap. ${ }^{24}$ "Rural" should, I think, only neutrally be used in opposition to "urban", and in my view it includes plant cultivation and animal husbandry as well as an important degree of settled life. Hence I find that the traditional view, which opposes settled and unsettled, is too monolithic. Although it appears from the Mari texts that genuine conflict

23 Hole I978; Kaplanian I973 (this MA thesis remains unpublished, but a summary can be found in Van Loon 2001, 607-648); Lewis I987. See also the summary in Schwartz I995, and the discussion in Meadow I992, $263 \mathrm{f}$. 24 The opposition is treated in Charpin 2004, esp. 84. Charpin interprets namlakatum rather more pointedly than Von Soden (AHw): "domaine peuplé de sédentaires" vs. "Herrschaftsgebiet". Nawûm means pastureland or steppe. In fact Charpin stipulates that the Mari texts themselves do not mention this opposition, it is so far only attested in texts from Tall Leilan (l.c. note 7). In the locus he cites, however (Eidem I987/8, II8), the association of nawûm and namlakatum may easily be seen as emphasizing the totality of possessions of the person called Mutiya. It is often the case in ancient Near Eastern enumerations that such totalities comprise overlapping entities as well as extremes like "alpha" and "omega". 
could occur between, e.g., the urban government and the 'sheikhs' of the people in the steppe, we might easily see this in terms of frustrated attempts by the ruling class of the city (who wrote the texts) to get a grip on every aspect of the lives of those not living within the immediate perimeter of the administration centre. Rather than speak of an opposition between settled and unsettled, we should therefore, as said above, speak of an opposition between town and country. The country, being filled with villages, hamlets and farmsteads which provided the towns and cities with their necessary items, and being subjected politically to administration attempts from the cities for that very reason, had always known a mixed economy ${ }^{25}$ where animal husbandry and cereal cultivation were necessarily combined, if only for the by-feeding of the herds of goats and sheep with barley. This mixed character of rural villages has in fact been known for a long time already, but it seems to have been snowed under by the persisting and I think rather tendentious French translation of hana* in Mari texts with nomades, which is then without further ado taken up as nomads in English, and Nomaden in German. ${ }^{26}$

Recapitulating, we have towns on the one hand, and the countryside on the other, and it is in this countryside that one is dealing with villages and hamlets, from where parts of the (presumably extended) families could set out for longer periods with the herds. They had their base in these settlements, but moved about frequently. The sheikhs in the Mari texts are almost always called "man of ...", where the place name involved clearly shows that these men had their bases in villages or even towns.

In this view, the incursions into the alluvium by the tribe of the Tidanum and the like, mentioned by the Ur III kings Šulgi and Šusin, might perhaps be seen as such occasions when the North Syrian and North Mesopotamian herdsmen apparently had reason to roam wider, and advance on the alluvium. ${ }^{27}$ The causes may have been political or economic: for the former we know of no easily identifiable reason yet, the latter can be sought in something like bad harvests and resulting famine (for which there is some sort of evidence only somewhat later, towards the end of Ibbi-Sin's reign - albeit there for southern Mesopotamia). We would, for this case of the Tidanum, be dealing with a special instance, on an extended scale, of a phenomenon that occurred very often on a smaller scale.

25 At least since the middle of the third millennium BC, cf. Meijer 2000.

26 See R. Kupper s.v. Hana in RlA IVI I972, 75, citing ARM VIII no. II. See also the comments on that text by Matthews I978, 34. 69. IIo. Stol 2004, 645f. uses the German term Nomaden. In his RlA contribution, Kupper calls the Hana people "semi-nomades", and clearly attributes mixed ways of life to them.

27 Meijer I999. 


\section{Archaeology and "movers"}

Much has recently been written about the possibilities and difficulties of identifying nomads and pastoralists through material remains. ${ }^{28}$ Traces of seasonal camps in the steppe are ephemeral and may have vanished throughout the millennia that have passed since the period of concern: they have suffered from being walked over, as well as from extended cultivation through motorized irrigation, and also through transformation into more permanent settlements even into our own times. For the region between Deir ez-Zor and Abu Kemal, for instance, Reculeau mentions the number of at least 86 rural sites known from the Mari texts, whereas archaeology only revealed 27 so far. ${ }^{29}$

In the present case, if we agree that most pastoralists had a home in the existing and identifiable villages, the implication is that little - or at least less than in the case of "real" constantly moving nomads - durable stuff would have been taken along on their trips: they left the cumbersome things at home, to be used by the remainder of the family or to be stored. The only trace one would find of their specific way of life might be sought in exaggerated amounts of storage space, animal bones, and other indirect evidence in those settlements. But what does exaggerated mean here?

I am afraid that we simply have no way to gauge relative amounts of "pastoralism" going on through archaeological means. Although we can hypothesize certain amounts of static emphasis on one aspect or another, and may even think we notice dynamic shifts between those aspects, 30 it is often on the basis of very little, badly comparable, and highly unrepresentative material that we do so. And, unfortunately, we also do it with a terminology that proves difficult to agree on.

But what contribution can archaeology make on the positive side? Since the seventies a number of surface surveys have been conducted (notably mostly along or close to major rivers and wadis), and a limited number of excavations added significantly to our database. The aggregate impression one gains from the surveys is that settlement in the Jazirah fluctuated between ca. 2300 and I700 BC, but showed a general increase in the last Ioo years of that period. Explanation, however, proves to be a different matter. ${ }^{\text {I }}$ Our increasing knowledge now necessitates more pointed and better informed questions than in the fifties, when Kupper's seminal and ground-breaking study of the Nomads ... in the time of the kings of Mari appeared, which may be acknowledged as the basis for all subsequent research. The

28 Cf. Banning - Köhler-Rollefson I992, Bartl I999, Bernbeck I993, Cole I975, and Cribb I99I, to name but a few authors.

29 Reculeau 2009, 72.

30 Cf., e.g., McCorriston's Fibre Revolution (McCorriston I997), Zeder's Specialized Herding (Zeder I998).

3I A recent Leiden dissertation evaluates modern data on surveys in the region (Wossink 2009, I34f.). For the Balikh region the MB II period shows the highest population increase; the Birecik region shows a lower increase at that time, but the more easterly Jazirah again shows a large increase - as was already suggested in Meijer I986. There are, however, important micro-regional differences. Wossink sets the increase in settlement off against site size; the overall conclusion supports what I call the "filling up" of the region with small sites. 
increased archaeological knowledge shows up fascinating and enticing discrepancies. It is striking that the area west of the Jaghjagh, for instance, in a survey conducted by Bertille Lyonnet (2000), produced little Khabur ware, which is seen as a hallmark of Middle Bronze Age occupation. Yet, a survey by me ${ }^{2}$ to the east of that river showed up rather more of that material, whereas the two regions do not look very different at all at first sight. We do neither know what is at play here, nor how good a gauge Khabur ware really is for the Middle Bronze Age. 33 Similarly, an intensive survey around Tall Baydar seems to indicate that occupation there in the MBA was scant. Why, since the EB occupation is clearly so well established? At first sight, then, archaeological data may not directly be conducive to detailed interpretation of the past. Yet, these data can perhaps be tied into the question of the character of the settlement and the way the settlers fed themselves.

\section{Conclusion}

The interpretation of rural life given above, in which a not-so-specialized pastoralism is suggested for the Syrian Jazirah during the Middle Bronze Age, cannot be proven with direct evidence. It is a hypothesis, and the result of reading between the cuneiform lines and looking at the modern world, in combination with survey and excavation data. Survey data suggest that at least the Balikh Valley knew a relatively constant, sometimes increasing amount of settled area, and excavations at Hammam at-Turkman suggest a flourishing regional centre. 34 More to the east such data are somewhat equivocal. If specialized pastoralism, or even nomadism as defined above, had developed in the region and period under discussion, one of the concomitant archaeologically recognizable effects should be the dissolution of settlements, provided there were no sudden increase in population; for if there had been such a vast and sudden influx one could make a case for pastoralists who made out that extra, invisible population. But the latter possibility is discarded on the basis of the discussion in Meijer 2000: there, an increase in settled, i.e. visible population is reckoned with, but their livelihood is taken to have consisted of the mixture of cultivation and herding advocated above, sprinkled with doses of trade. The important variable in our hypothesis is the noted increase in settlement, the "filling up" of the countryside with centres that claim suzerainty over their region, and with their dependent villages and hamlets.

This argument also shows where more work is needed: intensive surveys of the countryside in such areas as that between the valleys of the Balikh and Khabur, along the

32 Meijer I986.

33 Both questions are now treated in Wossink 2009, 97.

34 Both phenomena are discussed in Meijer 2007. In the northern Balikh Valley there is an increase from EB IV to MB II from I6 sites with an aggregate of 35.5 ha. settled area to 39 sites with an aggregate of 54.4 ha. During the same period the southern half of the valley shows respectively II sites for 25.4 ha, and 24 sites for 35.2 ha. Cf. now also Wossink 2009, $87 \mathrm{f}$. 
200mm isohyet. It is here that a better understanding of the relationship is needed between the known regional and interregional centres (e.g., Hammam, Chuera, Beydar) and any amount of smaller settlements still to be found. These surveys should then be extended southwards into the veritable steppe-area.

Above I repeated my conviction that important urban centres sprouted up just in those areas where, because of the marginal character of the area in terms of rain-fed agriculture, the contact of crop-cultivators and herdsmen was optimal: this border areas of steppic regions. There, logistically speaking, everyone had to expend the least effort to meet, and trade followed the routes connecting those places. Towns like Aleppo, Damascus, Hama, Ebla, Tall Chuera and also smaller towns like Hammam al-Turkman lie in or close to this zone of the marginal 300-200mm annual rainfall. These major and minor sites became surrounded with hamlets. One imagines townsmen receiving - in the town market - the produce of the herders, and the latter perhaps acquiring tools and other handicraft products. The increased number of settlements as compared to what we see in the later phases of the Early Bronze Age, also in rural areas further away from towns, and increasingly also in these steppe areas, suggests that a much more variegated situation obtained than has been hitherto imagined. The major centres had by now claimed all the available usable land, be it agricultural or for pasture. The domesticated camel had not yet been introduced, making the crossing of genuine desert areas less feasible. Centres such as Mari tried to control the usable countryside since it was their produce garden, and since settled people are easier to control than roamers, settlement was encouraged. There is room, I think, for expanding this view, as a hypothesis, to the following picture with a resulting change of perspective.

Villages and hamlets in the countryside were inhabited by people of mixed ethnic affiliation. Such people were engaged in both agriculture and pastoralism, i.e. crop cultivation and herding animals, some for themselves, some perhaps in the service of urban institutions such as a palace. Markets, both in the major towns and between the smaller settlements were provisioned with mixed produce, i.e. from both agriculture and the herd in a non-specialized way. I think we are dealing with non-specialized pastoralism, pace Buccellati ı990.

Already in my Paris paper (see note I) I mentioned Geyer's work in the steppe southeast of Aleppo as providing important opportunities for further research into the question of steppe settlement. 35 The subsequent excavations of Castel and her team in the fayda site of Rawdah have started to do just that. ${ }^{36}$ So-called fayda's are places in the steppe where the little rain that does fall, through the particular configuration of the soil, is collected and provides a sufficient reservoir under the surface for limited, but not necessarily very small-

35 Geyer 200I.

36 E.g. Castel 2005 . 
scale agriculture. ${ }^{37}$ The town of Rawdah existed on agriculture and herding, and trade, between ca. 2500 and $2000 \mathrm{BC}$, i.e. it became deserted at the beginning of our period of concern, but the potential of sites like Rawdah for our discussion is obvious. We clearly need more concentrated survey and excavation in the areas formerly neglected as unfeasible for habitation. This to see if perhaps, even if only for short periods per site, such temporary fayda-settlements did not exist in much greater numbers and in much more inhospitable areas than we thought; that would then facilitate the realization of the picture painted above, where even in the steppe formerly thought uninhabitable, there were settlements or hamlets, where people from the same families engaged in mixed farming and animal husbandry.

As a result, the opposition settled vs. nomadic would be replaced by the less stringent opposition urban-rural. Obviously a certain amount of "contrast" could indeed be felt by both the urbanites who wrote the texts and by the rural people, since like everywhere, producers resist attempts at control of their resources by others. I think it is more realistic, on the basis of archaeological data such as settlement distribution, to suggest that these rural producers lived in villages and hamlets from where they practiced cultivation as well as pastoralism, and from where they traded or delivered their produce when necessary.

Instead of Rowton's dimorphism, which still suggests a sharp division, I would therefore prefer a term like active symbiosis. It provides a wider scope for the intricate productive interplay of rural elements among themselves as well as with the population of urban centres - who were after all directly dependent on the countryside for their food. Much of this hypothetical picture rests, of course, on our gauge of who owned land, labour and transport. Therefore it is clear that future work should be two-pronged: archaeologists and geomorphologists should intensively concentrate their efforts on steppe areas, and philologists should concentrate on matters of ownership and use of land and animals in the period under consideration. The admirably liberal policies of the Syrian General Directorate of Antiquities, and hopefully those of its Iraqi counterpart in the very near future, will no doubt facilitate such progress in both fields. It is fascinating to see how the same tracts of land can be used in such different ways and within such different socio-economic frameworks throughout history. The Bedouin who roamed the area in sub-recent times have unwittingly defined our perception of what pastoral nomadism in the Ancient Near East should have looked like, but they formed only one in a long series of social constellations in the area. I hope that a term like active symbiosis will prove to represent Middle Bronze Age pastoralism more realistically. 


\section{Bibliography}

\section{Adams 1974}

R. M. Adams, The Mesopotamian Social Landscape: a View from the Frontier, in: Ch. B. Moore (ed.), Reconstructing Complex Societies, BASOR 20, I974, I-II.

\section{Banning - Kohler-Rollefson 1992}

E. B. Banning - I. Kohler-Rollefson, Ethnographic Lessons for the Pastoral Past: Camp Locations and Material Remains near Beidha, Southern Jordan, in: O. Bar-Yosef - A. Khazanov (eds.), Pastoralism in the Levant (Cambridge I992) I8I-204.

\section{Bartl 1999}

K. Bartl, Nomaden im archäologischen Kontext, in: H. Kühne - R. Bernbeck - K. Bartl (eds.), Fluchtpunkt Uruk. Schriften für Hans Jörg Nissen (Espelkamp I999) 87-94.

\section{Bates 1973}

D. G. Bates, Nomads and Farmers: A Study of the Yörük of Southeastern Turkey (Ann Arbor I973).

\section{Bernbeck 1992}

R. Bernbeck, Steppe als Kulturlandschaft (Berlin I992).

\section{Bernbeck 2008}

R. Bernbeck, An Archaeology of Multi-Sited Communities, in: H. Barnard - W. Wendrich (eds.), The Archaeology of Mobility (Los Angeles 2008) 43-77.

\section{Buccellati 1966}

G. Buccellati, The Amorites of the Ur III Period (Neapel I966).

\section{Buccellati 1990}

G. Buccellati, 'River Bank', 'High Country' and 'Pasture Land': The Growth of Nomadism on the Middle Euphrates and the Khabur, in: S. Eichler - M. Wäfler - D. Warburton (eds.), Tall al-Hamidiya 2 (Freiburg I990) 87-II7.

\section{Castel 2005}

C. Castel, Rapport preliminaire sur les activites de la mission archeologique franco syrienne dans la micro-region d'Al-Rawda (Shamiyeh): deuxieme et troisieme campagnes (2003 et 2004), Akkadica I26, 2005, 5I-96.

\section{Charpin 1990}

D. Charpin, Les mots du pouvoir dans les archives royales de Mari (XVIIIème siècle av. J.-C.), Cahiers du centre Gustave Glotz 2, I990, 3-I7.

\section{Charpin 200I}

D. Charpin, L'Archivage des tablettes dans le palais de Mari: nouvelles données, in: W. H. van Soldt (ed.), Veenhof Anniversary Volume, PIHANS 89 (Istanbul 200I) I3-30.

\section{Charpin 2004}

D. Charpin, Nomades et sédentaires dans l'armée de Mari du temps de Yahdun-Lim, in: C. Nicolle (ed.), Nomades et sédentaires dans le Proche-Orient ancient, Amurru 3 (Paris 2004) 83-94. 


\section{Cole 1975}

D. P. Cole, Nomads of the Nomads (Illinois I975).

\section{Cribb 1990}

R. Cribb, Nomads in Archaeology (Cambridge I990).

\section{van Driel 1999}

G. van Driel, The Role of Nomadism in a Model of Ancient Mesopotamian Society and Economy, JEOL 35/36, I997-2000, 85-IOI.

\section{Eidem $1987 / 8$}

J. Eidem, Tell Leilan Tablets I987 - A Preliminary Report, AAS 38/39, I987/8, IIO-I27.

\section{Emberling - Yoffee 1999}

G. Emberling - N. Yoffee, Thinking about Ethnicity in Mesopotamian Archaeology and History, in: H. Kühne - R. Bernbeck - K. Bartl (eds.), Fluchtpunkt Uruk. Schriften für Hans Jörg Nissen (Espelkamp I999) 272-28I.

\section{Freydank 1980}

H. Freydank, Zur Lage der deportierten Hurriter in Assyrien, AoF 7, I980, 89-II7.

\section{Geyer 200I}

B. Greyer, Conquête de la steppe et appropriation des terres sur les marges arides du Croissant fertile (Lyon 200I).

\section{Hole 1978}

F. Hole, Pastoral Nomadism in Western Iran, in: R. A. Gould (ed.), Explorations in Ethnoarchaeology (Albuquerque I978) I27-I67.

\section{Kaplanian 1973}

B. Kaplanian, Selenkahiye: A Village in Syria. Unpublished MA thesis, University of Amsterdam. (a short summary is to be found in van Loon 200I).

\section{Khazanov 1984}

A. Khazanov, Nomads and the Outside World (Cambridge I984).

\section{Khazanov 2009}

A. Khazanov, Specific Characteristics of Chalcolithic and Bronze Age Pastoralism in the Near East, in: J. Szuchman (ed.), Nomads, Tribes, and the State in the Ancient Near East. Crossdisciplinary Perspectives (Chicago 2009) II9-I27.

\section{Larsen 1988}

M. T. Larsen, Introduction: Literacy and Social Complexity, in: J. Gledhill - B. Bender M. Larsen (eds.), State and Society (London I988) I73-I9I.

\section{Lewis 1987}

N. N. Lewis, Nomads and Settlers in Syria and Jordan, 1800-1980 (Cambridge I987).

\section{Lion 1996}

B. Lion, Les contacts entre Hourites et Sémites en Haute-Mésopotamie au IIe millénaire av. J.-C., Cahiers du centre Gustave-Glotz 7, 1996, 7-24. 
van Loon 200I

M. N. van Loon, Selenkahiye. Final Report on the University of Chicago and University of Amsterdam Excavations in the Tabqa Reservoir, Northern Syria, I967-I975, PIHANS 9I (Istanbul 200I).

\section{Lyonnet 1999}

B. Lyonnet (ed.), Prospection archéologique du haut-Khabur occidental (Syrie du N.E.). Volume I (Beyrouth i999).

Matthews 1978

V. H. Matthews, Pastoral Nomadism in the Mari Kingdom (Cambridge I978).

\section{McCorriston 1997}

J. McCorriston, The Fiber Revolution. Textile Extensification, Alienation, and Social Stratification in Ancient Mesopotamia, Current Anthropology 38, I997, 517-549.

\section{Meadow 1992}

R. H. Meadow, Inconclusive Remarks on Pastoralism, Nomadism, and Other AnimalRelated Matters, in: O. Bar-Yosef - A. Khazanov (eds.), Pastoralism in the Levant (Madison 1992) 26I-269.

\section{Meijer 1986}

D. J. W. Meijer, A Survey in Northeastern Syria, PIHANS 58 (Istanbul I986).

\section{Meijer 1999}

D. J. W. Meijer, Ecology and Archaeology: Perceptions and Questions, in: L. Milano - S. de Martino - F. M. Fales - G. B. Lanfranchi (eds.), Landscapes. Territories, Frontiers and Horizons in the Ancient Near East (Padova 2000) 203-2II.

\section{Meijer 2007}

D. J. W. Meijer, The Area of the Balikh Between ca. 2500 and I700 BC., in: P. Matthiae F. Pinnock (eds.), From Relative Chronology to Absolute Chronology: The Second Millennium BC in Syria-Palestine, Proceedings of the International Colloquium, Rome 29th November - Ist December 200I (Roma 2007) 313-326.

\section{Musil I928}

A. Musil, The Manners and Customs of the Rwala Bedouins (New York I928).

\section{Nicolle 2004}

C. Nicolle (ed.), Nomades et sédentaires dans le Proche-Orient ancient, Compte rendu de la XLVIe Rencontre Assyriologique Internationale. Paris, IO-I3 juillet 2000, Amurru 3 (Paris 2004).

\section{von Oppenheim I939}

M. von Oppenheim, Die Bedouinen, I-IV (Leipzig I939-1968).

\section{Reculeau 2008}

H. Reculeau, "II. Les sédentaires", in: Tell Hariri-Mari, Textes. Supplément au dictionnaire de la Bible, fasc. 77-78 (tome XIV) (Paris 2008) 324-356. 


\section{Reculeau 2009}

H. Reculeau, L'implantation sédentaire dans la vallée de l'Euphrate à l'age du bronze. Un modèle centre/périphérie?, in: J.-M. Durand - A. Jacquet (eds.), Centre et Périphérie: approaches nouvelles des Orientalistes (Paris 2009) 57-8I.

\section{Rowton 1980}

M. B. Rowton, Pastoralism and the Periphery in Evolutionary Perspective, in: M.-Th. Barrelet (ed.), l'Archéologie de l’Iraq (Paris I980) 29I-30I.

\section{Schwartz 1995}

G. Schwartz, Pastoral Nomadism in Western Asia, in: J. M. Sasson (ed.), Civilizations of the Ancient Near East (New York 1995) 249-258.

\section{Shibutani - Kwan 1965}

T. Shibutani - K. M. Kwan, Ethnic Stratification: A Comparative Approach (New York I965).

van Soldt et al. 2005

W. H. van Soldt - R. Kalvelagen - D. Katz, Ethnicity in Ancient Mesopotamia, PIHANS IO2 (Istanbul 2005).

\section{Stol 2004}

M. Stol, Wirtschaft und Gesellschaft in Altbabylonischer Zeit, in: P. Attinger et al. (eds.), Mesopotamien. Annäherungen 4: Die Altbabylonische Zeit, OBO I60/4 (Fribourg 2004) 64I-975

\section{Streck 2002}

M. Streck, Zwischen Weide, Dorf und Stadt: Sozio-ökonomische Strukturen des amurritischen Nomadismus am Mittleren Euphrat, Baghdader Mitteilungen 33, 2002, I55-209.

\section{Szuchman 2009}

J. Szuchman (ed.), Nomads, Tribes, and the State in the Ancient Near East. Cross disciplinary Perspectives (Chicago 2009).

\section{Thesiger 1959}

W. Thesiger, Arabian Sands (London 1959).

\section{Wirth I97I}

E. Wirth, Syrien. Eine Geographische Landeskunde (Darmstadt I97I).

\section{Wossink 2009}

A. Wossink, Challenging Climate Change. Competition and Cooperation among Pastoralists and Agriculturalists in Northern Mesopotamia (c. 3000-I600BC) (Leiden 2009).

\section{Zeder 1998}

M. Zeder, Environment, Economy and Subsistence on the Threshold of Urban Emergence in Northern Mesopotamia, in: M. Fortin - O. Aurenche (eds.), Espace Naturel, espace habité en Syrie du Nord (Lyon I998) 55-67.

\section{Zohar 1992}

M. Zohar, Pastoralism and the Spread of the Semitic Languages, in: O. Bar-Yosef - A. Khazanov (eds.), Pastoralism in the Levant (Madison I992) I65-I8. 